\title{
Facing global water problems: the legacy of Yu the Great
}

\author{
W. Ravesteijn \\ Section of Technology Dynamics \& Sustainable Development, \\ Delft University of Technology, The Netherlands
}

\begin{abstract}
China is one of the countries where the water situation is dramatic. The country is faced with increasing pressure on its scarce water resources, expanding water pollution and degrading aquatic environments, beside severe flooding problems. This paper - based on desk research and fieldwork - shows how China deals with its water problems and what the prospects are for necessary changes or transitions in its water management and development approach, focussed on flooding. Chinese water-problem solving and its potential for change are, on the one hand, compared with approaches, practices and trends elsewhere in the world and, on the other hand, placed in the context of the country's water tradition with its distinction between Confucian and Taoist approaches and its emphasis on large-scale projects. The Chinese water tradition, inspired by Yu the Great, will not only appear to be helpful in coming to grips with Chinese water management and development and in providing a perspective on a new approach, but also to be significant for water transition studies and policies in general.

Keywords: flooding, water transitions, integrated river basin management, Dutch water management and development, room for the water, Confucian and Taoist water engineering.
\end{abstract}

\section{Introduction}

Given the grand challenges in the water domain world-wide, the time has come to reflect on existing practices and approaches and consider sustainable and responsible alternatives, aimed at economic, efficient and equitable ways of dealing with water issues. Water stress is particularly serious in poor and emerging countries, though rich and developed countries are affected as well. 
Both types of countries - and all countries in between - require a "water transition" or, better, transitions in a variety of respects. China is one of the countries where the water situation is dramatic, especially in terms of water scarcity, water pollution and flooding. In other fields, like energy and urban planning, China shows great determination in tackling sustainability problems, for example through renewable (particularly wind and solar) energy technologies and eco-industrial parks, cities and ports (e.g. Global Wind Energy Council [1], Liu et al. [2], Geng and Doberstein [3], Qiu [4], Wu [5], Joss et al. [6]). The question is what the possibilities and chances are for a shift in water resources management and development.

This paper - based on desk research and fieldwork - shows how China deals with its water problems and what the perspectives are for a necessary transition in its water management and development approach, focussed on river flooding. It uses, on the one hand, a comparative perspective, highly relevant because water management and development are very much the scene of global circulation of scientific knowledge and technologies. My special reference case will be the Netherlands, though from a European perspective. On the other hand, Chinese water problem-solving is placed in the context of the country's water tradition with its distinction between Confucian and Taoist approaches and its emphasis on large-scale projects. It will be argued that this distinction, introduced by the famous sinologist Joseph Needham (1900-1995), does more justice to the socio-cultural dimensions of water engineering and control than a similar Western distinction between construction and management-oriented approaches. In addition, it will appear to be helpful for getting a better understanding of the dynamics in the water domain and thus in offering us possibilities for intervention on behalf of necessary changes, both in China and elsewhere in the world.

In view of the world-wide water stress, this paper seeks to answer the following questions:

1. What transitions in water management and development are necessary?

2. What shifts in approaches and insights can be observed in the water domain?

3. What are the current approaches, trends and new insights regarding water in China?

4. What are the possibilities for water transitions in China?

5. How can the Chinese water tradition contribute to sustainable and responsible dealing with water problems in general?

First, two sections will deal with water problems and the responses they provoke, both theoretically (in terms of transitions) and in practice (in terms of current trends). A section devoted to our reference case: the Netherlands follows. Consequently, two sections will be devoted to China: present developments and transition potential. The answers to the questions above are prepared in these five sections and finally given - or summarized - in the concluding section. 


\section{Present-day water problems and necessary transitions}

There is a whole array of water issues facing the world community. The most serious are:

1. Water shortages: one third of the world's population is suffering from water shortages (International Water Management Institute [7]); by 2025 two-thirds will be affected (UNEP [8]).

2. Pollution: It has been suggested that it is the leading worldwide cause of deaths and diseases and that it accounts for the deaths of more than 14,000 people daily (Water Pollution [9]).

3. Flooding: More than half the world's population and more than 80 per cent of our cities are found in deltas prone to flooding from the sea or rivers (e.g. Fresco [10]).

These problems, caused and strengthened by population growth, economic development, urbanization and global warming, are not only threatening human life and health directly, they also introduce and increase distributional issues in terms of who profits and who suffers when it comes to water problems like scarcity, pollution and flooding.

Which responses are necessary? Tackling these challenges requires great changes in water resources management and development. Such changes are sometimes described as "transitions" (e.g. Geels [11], Geels and Schot [12], Berkhout et al. [13], Martens and Rotmans [14], Smith et al. [15]). Theoretically, transitions are combinations of "system" and "regime" changes in which relevant stakeholders take part. Their shape depends on the socio-political context. Though linearity is presumed, transitions can follow more than one pathway, including mixtures of pathways. When it comes to the required water transitions (cf. Hoekstra and Huynen [16], Ravesteijn et al. [17]), the following shifts seem to be - or in this framework are hypothesized to be - essential:

1. From a structural approach to a non-structural approach, from construction to management.

2. From top-down planning \& policies to more decentralized bottom-up approaches, with participation of stakeholders.

Which responses are visible? The emphasis here is on flooding problems, but it is undesirable if not impossible to focus on these problems only, as measures and policies are increasingly part of integrated approaches.

\section{Current trends in the water domain}

To address global water issues, three important transformations are visible in water resources management and development (Ravesteijn et al. [18]):

1. A shift towards higher levels of decision and policy making, accompanied by a larger and larger scale of operations, involving bigger and bigger works.

2. A shift in emphasis from constructing water works towards managing water flows. 
3. A shift from a control regime, to an adaptive water engineering and management regime.

Things culminate in Integrated Water Resources Management, Integrated River Basin Management and the Room for the Water policy.

While Integrated Water Resources Management came up in the third quarter of the twentieth century, e.g. in the Netherlands (see below), Integrated River Basin Management (IRBM) dates back longer (Kates and Burton [19]). The American geographer Gilbert White (1911-2006) coined the concept on the basis of a world-wide inventory of knowledge, experiences and practices. The Tennessee Valley Authority (1933) is a pioneering and internationally followed example, though it contained an extensive building programme and it lost much of its lustre, because of ecological and social problems. Still IRBM, with the emphasis on management, seems to become the dominant water regime in the (Western) world. The 2000 European Water Framework Directive (WFD) is a showcase, copied outside of Europe, e.g. in Turkey, India and China (see below) (Ravesteijn et al. [20]). Though it reflects the increasing centralization trend in water management, it also contains elements of decentralization. In fact, a main characteristic is its participatory approach. In this respect it is noteworthy that the WFD exemplifies the Negotiated Approach, though this new direction in water system building has especially emerged from small-scale, bottom-up initiatives, e.g. in Bangladesh (Ravesteijn et al. [17]). Additionally, new guiding principles are developing including Room for the Water, not only in the Netherlands, but also in e.g. Indonesia and the USA, and Virtual Water Trade, which asks attention for the water quantities involved in growing and producing crops and products and seeks to optimize water use in relation to local conditions (Ravesteijn et al. [17]).

\section{The Dutch and the water}

Historically, as a delta country, the Netherlands has been suffering from flooding (see fig. 1), while recently other problems came on top of that, especially pollution and, surprisingly, water shortages in particularly dry periods of the year; flooding is still there, though more as a threat than as a reality. Climate change, which leads world-wide, among other things, to rising seawater levels and changed river discharge patterns, seems to be an essential background. Population growth and economic development, though less pressing than in developing areas in the world, are still factors of importance.

Dutch responses to this increasing set of problems (Disco and Van der Vleuten [22], Ravesteijn and Kroesen [23]) include the introduction of Water Boards, often in combination with "polders", since the year 1000, combined with the establishment of a National Water Agency around 1800 in order to tackle the "big river problem": floods from especially the River Rhine and the River Meuse. The scale of water engineering rose in the course of time, with the construction of a dike to close the Southern Sea (the IJsselmeer Dam), the thereupon following construction of polders in the newly formed lake (the IJsselmeer) and the famous Delta works, including the Eastern Scheldt and 
Maeslant storm surge barriers, as impressive feats in the twentieth century. In the field of management, water boards came to cover bigger and bigger areas and, consequently, diminished in number, while Integrated Water Resources Management emerged around 1980. After more than a century of international cooperation and coordination in especially the River Rhine basin, true European river management has been introduced in 2000, when the European Parliament adopted the European Water Framework Directive (WFD). Apart from that, in the 1990s a transition has been set in motion from the traditional "Dry feet" regime to the new "Room for the water" regime, such in view of the "big river problem", that once again surfaced, possibly in connection with climate change.

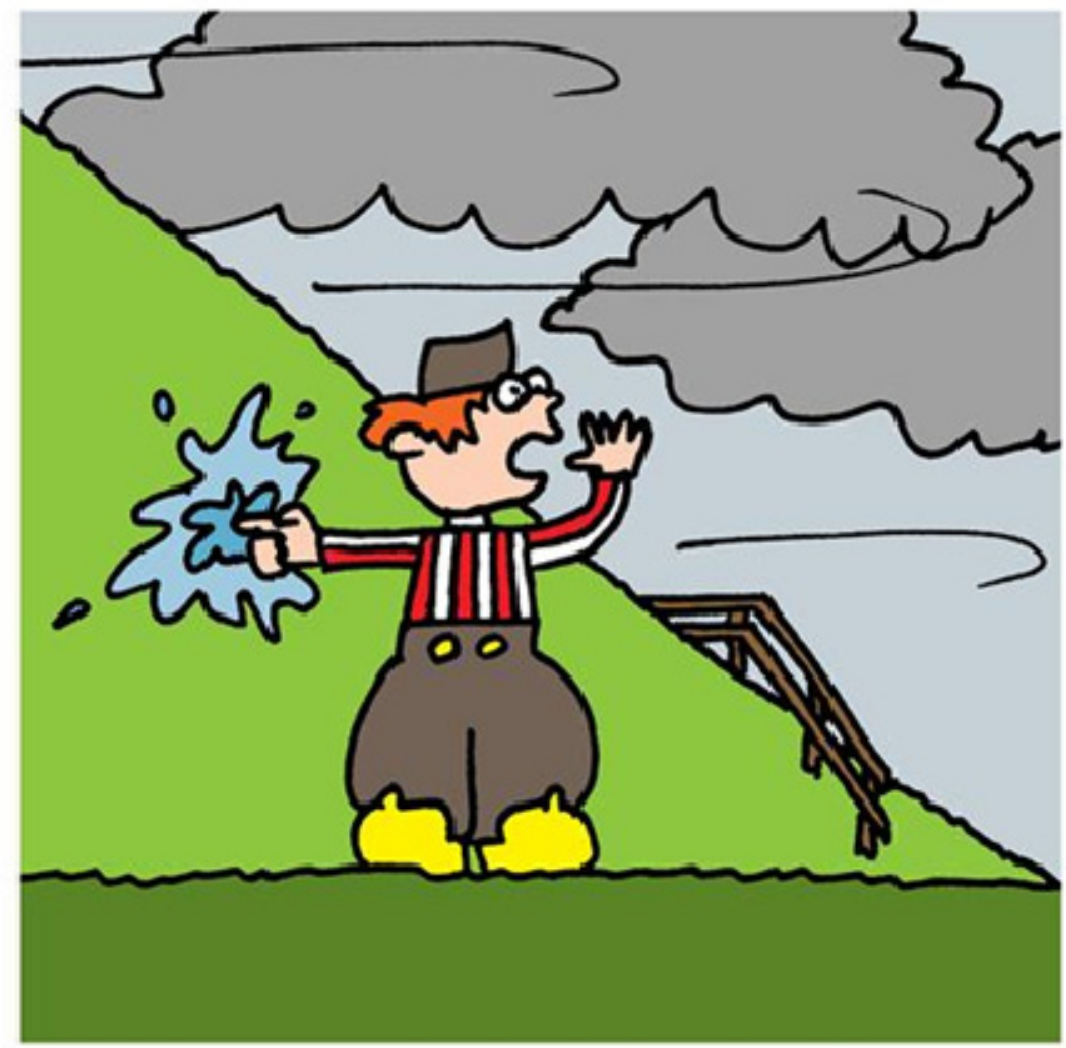

Figure 1: Hans Brinker, a Dutch boy who prevented a flood by plugging a dike with his finger (based on Mary Mapes Dodge's novel "Hans Brinker, or, the Silver Skates: A Story of Life in Holland” [21]). 


\section{Chinese water management and development}

China faces the same water issues as other countries, though in a special contextbound mixture and in ways that are more alarming than elsewhere. On the one hand, its water resources are scarce (China has $7 \%$ of the world water resources, while $20 \%$ of the population), on the other hand, the pressure is growing as a consequence of rapid urbanization, industrialization and economic development in general (9\% GDP growth in 2011). In addition, the country is faced with expanding water pollution and degrading aquatic environments, beside severe flooding problems. Beside its development dynamics, climate change is another factor at play, aggravating flooding and other problems.

In China the structural approach prevails, which appears e.g. from big dam building; the Three Gorges Dam is a case in point. The biggest project being implemented nowadays is the South-North Water Transfer plan, which aims to bring water from the wet South to the dry North, along three different routes (one of them the Grand Canal). Social aspects like resettlement have become an integral part of these projects, which consequently have become complete sociotechnical enterprises. IRBM, however, is increasingly being adopted, e.g. the WFD in the Yellow River basin (Ravesteijn et al. [20]). The 1988 Water Law introduced Integrated Water Management, though highly centralized, while the 2002 Amended Water Law provided for a combination of regional Integrated Water Management and IRBM. Stakeholder engagement, however, is low, though increasing (Song et al. [24]). Further, Room for the Water programmes are being introduced, e.g. the restoration of wetlands in the northern Songhua River basin (Song et al. [25], Zheng et al. [26]).

The challenges, however, in introducing IRBM are great (Song and Ravesteijn [27]). First of all, water laws, though favourable, are not properly enforced. Secondly, there is a variety of "comprehensive" water management institutions with strongly overlapping institutional roles and no effective coordination. Thirdly, water management is fragmented, including the separation of quantitative and qualitative management. Last but not least, water affairs are being handled through a top-down approach, with little public participation and transparency.

A water transition - or series of transitions - in China could include the following targets:

1. Emphasis on management rather than structures.

2. From a top-down to a more comprehensive strategy, including stakeholder involvement.

3. Full consideration of social and ecological aspects.

4. Shift to less water intensive production modes and lifestyles.

Would such a transition be possible in China?

\section{Chinese transition dynamics}

The Chinese water tradition includes large engineering feats, like the Grand Canal for the transportation of goods between the North and the South of the 
country, especially food (rice) from the very productive South to the North, where soldiers had to protect China against intrusive nomads (and workers had to construct the Great Wall) and were the political centre came to established (in Beijing). Construction the canal is supposed to have started around 2500 years ago. The Chinese water tradition dates back much further in time, till some 4000 years ago, when the famous $\mathrm{Yu}$ the Great (see fig. 2) is believed to have successfully fought the floods from the Yellow River, after which he established a new Chinese dynasty (Needham et al. [28], Song and Ravesteijn [27]).

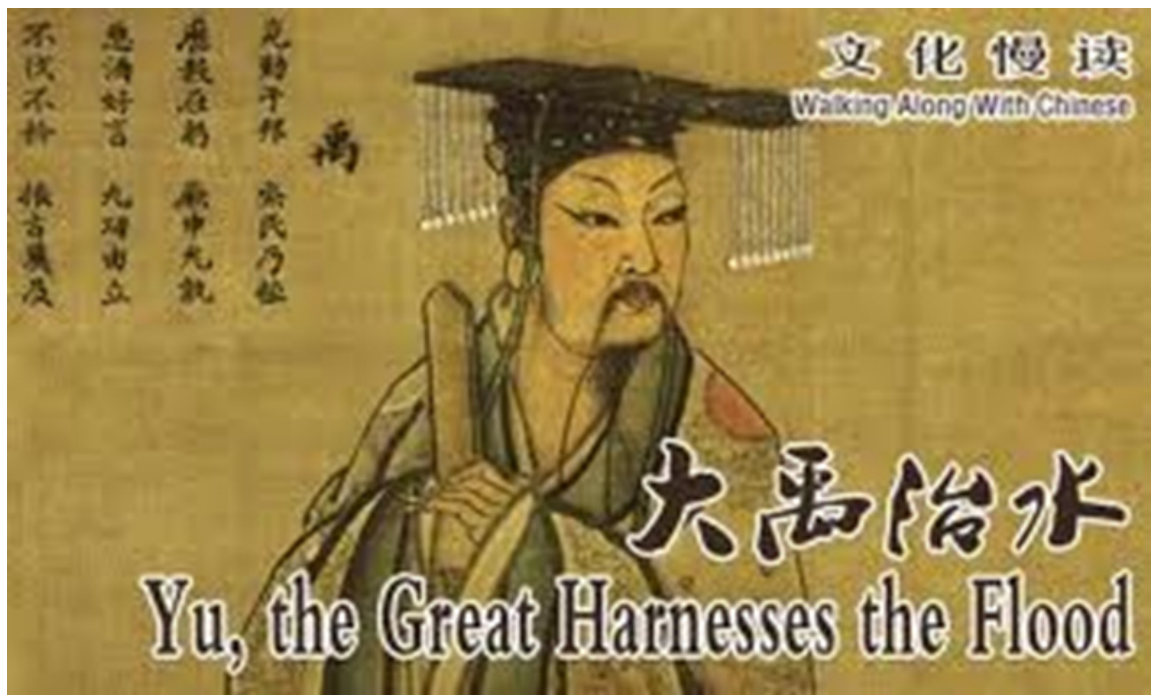

Figure 2: $\quad$ Yu the Great, the legendary founding father of the Chinese water tradition as well as the ancient Xia Dynasty [29].

Yu the Great succeeded were other failed (notably his supposed father Kun), by giving the water maximum freedom. The so-called Taoist engineers followed in his footsteps. Like Yu, they practiced "wu wei", which means that no action should be taken contrary to nature; nature should take her own course. The Taoists were "expansionists" in water engineering: they championed water letting take its own course as far as possible, giving it plenty of room. Consequently, dykes were set far apart. They could also be low, while the Taoists supported deep channels and dredging as well. What finally resulted from their efforts, was a great network of irrigation channels and retention basins (cf. [30]).

The Confucian engineers were their opposites. In terms of the traditional Chinese Yin-Yang philosophy, their approach was "masculine", instead of the Taoists' "feminine" approach. They championed confining and repressing nature. The Confucians were "contractionists" and disciplinarians, promoting strict rules and strong measures of control in their water activities. High and mighty dykes set near together was their thing. Contracting the channels, making 
the rivers dig their own beds, was their view. Later, they were in favour of large dam construction, which was expensive, but caused relatively less social problems (cf. Dodgen [31]).

Engineering and morality, profit and virtue, went hand in hand (Needham et al. [28]). Chia Jang, a Taoist engineer who lived some 3000 years ago, is reported to have said: "those who are good at controlling water give it the best opportunities to flow away; those who are good at controlling the people give them plenty of chance to talk" (quoted in: Needham et al. [28]). The Confucians had other views, they promoted laws comparing them with (high) dykes.

The interesting thing about the Chinese water tradition is that none of both engineering schools prevailed definitely. Both approaches were fruitful, both had their flaws. Taoist engineering necessitated the resettlement of people, while great sediment depositions not only reduced the storage capacity of basins, but also constituted temptations for farmers and communities to colonize the new land (and running the risk of flooding). Confucian engineering had other disadvantages, like bend erosion: the undermining of dykes at bends. As a result of their efforts, water levels could rise speedily, which created a safety problem. Consequently, the civil engineering history in China displays the constant dynamics of both schools, which often and increasingly resulted in some synthesis of both approaches.

Present-day engineering in China is more Confucian than Taoist, with an emphasis on construction of large works. The desired transitions, however, involve a shift to a new balance of the two approaches. In view of their historical dynamic interaction and synthesis, this would introduce just a new episode in a continuing effort. The high pace of economic development in China and all dynamics connected with that, seems to constitute a facilitating environment for sustainable development trajectories in water engineering and management as well as more in general.

\section{Conclusions}

This paper aims to answer the following four questions:

1. What transitions in water management and development are necessary?

2. What shifts in approaches and insights can be observed in the water domain?

3. What are the current approaches, trends and new insights regarding water in China?

4. What are the possibilities for water transitions in China?

5. How can the Chinese water tradition contribute to sustainable and responsible dealing with water problems in general?

The grand challenges in the domain of water require transitions in water resources management and development, which implies big changes, including:

1. From a controlling, structural approach to an adaptive, non-structural approach, from construction to management.

2. From top-down planning and policy to more decentralized bottom-up approaches, with participation of stakeholders. 
World-wide, the water domain shows a lot of change and development, especially:

1. A shift towards higher levels of decision and policy making, accompanied by a larger and larger scale of operations, involving bigger and bigger works.

2. A shift in emphasis from constructing water works towards managing water flows.

3. A shift from a control regime, to an adaptive water engineering and management regime.

Are these changes leading to the necessary water transitions? They definitely imply - or are part of - system innovations and regime shifts, though a more systematic steering of these transformations would help. There seems to be some tension between, on the one hand, a shift towards higher levels of management and, on the other hand, the necessary inclusion of stakeholders. However, efforts are being done to reconcile centralization and decentralization, e.g. in the European Water Framework Directive. The old adage might be applicable here: centralization where necessary, decentralization where possible. In its waterproblem solving, China shows a slow shift of emphasis from construction to management, including participation, as well as some change from a more restraining to a more adaptive regime. Its potential for water transitions, however, is great. The Chinese water engineering and management tradition displays two approaches: Confucian engineers underlined strict control of the water, while Taoist engineers gave it maximum freedom. Presently, the Confucian approach is very much in control, as is evidenced by big projects recently carried out or in progress. The time is ripe, however, for a Taoist shift to a new balance of both engineering approaches, which fits in perfectly with its dynamic Taoist-Confucian history of water engineering and management, as acknowledged and elaborated in Delft $\mathrm{PhD}$ research ( $\mathrm{Li}$ [32]).

All water engineering, management and transition knowledge is based on and part of a world-wide circulation of ideas, experts, firms, financial resources, et cetera. Usually China is considered to be a "receiving" country where a lot could be learned from the West and this belief is also very widespread in China itself, as evidenced by its open market and reform policies since the end of the 1970s (e.g. De Jong et al. [33], De Jong et al. [34]). Here, however, the question asked is: what lessons could be learned from China?

First of all, that the Room for the Water approach is not new and certainly not a Dutch innovation: it goes back to the very origins of China, when Yu the Great established his name 4000 years ago. He succeeded where others failed laying the foundations for the Taoist approach as well as a water tradition in which there was no one and only truth, but a dynamics of Taoist and Confucian approaches. Secondly, the Chinese water tradition clearly shows the relationship between engineering and morality, as acknowledged and elaborated in Delft PhD research (Van Heezik [35]). Thirdly, the latter shows the embeddedness of water engineering and management in broader society. Consequently, Confucian and Taoist water approaches and connected systems of morality provide an enlightening framework for understanding and stimulating transitions, opening 
perspectives on both bringing about change and our limitations for intervention. In sum, the Chinese water history not only turns out to be helpful in coming to grips with Chinese water management and development, but it is also to significant for water transition studies and policies in general.

\section{References}

[1] Global Wind Energy Council, Global Wind Report 2010, http://www.gwec.net/fileadmin/images/Publications/GWEC_annual_marke t_update_2010_-_2nd_edition_April_2011.pdf.

[2] Liu, L., Wang, Z., Zhang, H. and Xue, Y., Solar Energy in China: A Review. Renewable and Sustainable Energy Reviews, 14(1), pp. 301-311, 2010.

[3] Geng, Y. and Doberstein, B., Developing the circular economy in China: Challenges and opportunities for achieving 'leapfrog development'. International Journal of Sustainable Development \& World Ecology 15(3), pp. 231-239, 2008.

[4] Qiu, B., The Transformation Trends of Urban Development Model in China: Low Carbon Eco-city. Urban Studies, 2009-08.

[5] Wu, F., China's eco-cities. Geoforum, 43 (2), pp. 169-173, 2012.

[6] Joss, S., Kargon, R. and Molella, A., 2013. Eco-Cities in Pan-Asia: International Discourses, Local Practices. From the Guest Editors. Journal of Urban Technology, 20(1), pp. 1-5, 2013.

[7] International Water Management Institute, http://www.iwmi.cgiar.org/.

[8] UNEP, http://www.unep.org/geo/geo4/report/04_water.pdf.

[9] Water Pollution, http://en.wikipedia.org/wiki/Water_pollution.

[10] Fresco, L., http://weblogs.nrc.nl/discussion/2008/11/21/how-to-protectourselves-from-floods/.

[11] Geels, F.W., Processes and patterns in transitions and system innovations: Refining the co-evolutionary multi-level perspective. Technological Forecasting \& Social Change, 72(6), pp. 681-696, 2005.

[12] Geels, F.W. and Schot, J., Typology of sociotechnical transition pathways. Research Policy, 36(3), pp. 399-417, 2007.

[13] Berkhout, F., Smith, A. and Stirling, A., Socio-technical regimes and transition contexts. System Innovation and the Transition to Sustainability, eds. B. Elzen, F.W. Geels and K. Green, Edward Elgar Publishing: Cheltenham/Northampton, pp. 48-75, 2004.

[14] Martens, P. and Rotmans, J. (eds.), Transitions in a globalising world. Lisse: Swets \& Zeitlinger Publishers, pp. 17-35, 2002.

[15] Smith, A., Stirling, A. and Berkhout, F., The governance of sustainable socio-technical transitions. Research Policy, 34(10), pp. 1491-1510, 2005.

[16] Hoekstra, A.Y. and Huynen, M., Balancing the world water demand and supply. Transitions in a Globalising World, eds. P. Martens \& J. Rotmans, Swets \& Zeitlinger Publishers: Lisse, pp. 17-35, 2002.

[17] Ravesteijn, W., Kroesen, O., Firoozyar, F. and Song, X., River systems in transition: pathways and stakeholder involvement. WIT Transactions on 
Ecology and the Environment, 126, pp. 327-339, 2011. Also published in: River Basin Management VI, ed. C.A. Brebbia, WIT Press: Southampton, 2011; and in: Transactions of the Wessex Institute, eLibrary, http://library.witpress.com/pages/PaperInfo.asp?PaperID=20543.

[18] Ravesteijn, W., Hermans, L. and Vleuten, E. van der, Water systems. Participation and globalisation in water system building. Special issue of Knowledge, Technology \& Policy, 14(4), 2002.

[19] Kates, R.W. and Burton, I. (eds.), Geography, Resources and Environment. Vol. 2: Themes from the Work of Gilbert F. White. The University of Chicago Press: Chicago, 1986.

[20] Ravesteijn, W., Song, X., and Wennersten, R., The 2000 EU water framework directive and Chinese water management: experiences and perspectives. WIT Transactions on Ecology and the Environment, 124, pp. 37-46, 2009. Also published in: River Basin Management V, ed. C.A. Brebbia, WIT Press: Southampton, 2009; and in: Transactions of the Wessex Institute, eLibrary, http://library.witpress.com/pages/PaperInfo .asp?PaperID=20543.

[21] Hans Brinker (picture), http://www.aaenmaas.nl/informatie_op_maat/ kinderen_0/kinderen/kids/dijk_weetjes?Id=2305935.

[22] Disco, C. and Vleuten, E. van der, The politics of wet system building: Balancing interests in Dutch water management from the middle ages to the present. Knowledge, Technology \& Policy, 14(4), pp. 21-40, 2002.

[23] Ravesteijn, W. and Kroesen, O., Tensions in water management: Dutch tradition and European policy. Water Science \& Technology, 56 (4), pp. 105-111, 2007.

[24] Song, X., Mulder, K., Frostell, B., Ravesteijn, W., and Wennersten, R., Transition in Public Participation in Chinese Water Management. Engineering Sustainability: Proceedings of the Institution of Civil Engineers, 164 (ES1), pp. 71-83, 2011.

[25] Song, X., Ravesteijn, W., Frostell, B. and Wennersten, R., Managing Water Resources for Sustainable Development: The Case of Integrated River Basin Management in China. Water Science \& Technology, 61 (2), pp. 499-506, 2010.

[26] Zheng, D., Mi, J., Ravesteijn, W. and Qiu, F., Resource Management and Stakeholders: The Predicament and Reform Path of Chinese Wetland Conservation. Work in progress.

[27] Song, X. and Ravesteijn, W., Dilemmas in Water Systems Development in China. What is Sustainable Technology? Struggles and dilemmas regarding articulations of Sustainable Development, eds. K. Mulder, D.F. Balas and H. van Lente, Greenleaf: Sheffield, 2011.

[28] Needham, J., Wang Ling and Lu Gwei-Djen, Civil Engineering and Nautics. Science and Civilisation in China, Vol. 4, Part 3, ed. J. Needham, Cambridge University Press: Cambridge, 1971.

[29] $\mathrm{Yu}$ the Great (picture), http://people.chinese.cn/article/201009/03/content_169971.htm. 
[30] Tillman Lyle, J., Design for human ecosystems: landscape, land use, and natural resources, Van Nostrand Reinhold: New York, 1999.

[31] Dodgen, R.A., Controlling the Dragon: Confucian Engineers and the Yellow River in Late Imperial China, University of Hawai'i Press: Honolulu, 2001.

[32] Li R., Application of Equity principles of IWRM in water allocation in the Yellow River Basin, Optima Grafische Communicatie: Rotterdam, 2008 (dissertation TU Delft).

[33] Jong, W.M. de, Lalenis, K. and Mamadouh, V. (eds.), The Theory and Practice of Institutional Transplantation; Experiences with the Transfer of Policy Institutions, Kluwer Academic Publishers: Dordrecht, 2002.

[34] Jong, W.M. de, Waaub, J. P. and Kroesen, O., Cross-national policy transfer to developing countries: Prologue. Knowledge, Technology \& Policy, 19(4), pp. 3-8, 2007.

[35] Heezik, A. van, Battle over the Rivers: Two Hundred Years of River Policy in the Netherlands. Beleidsresearch.nl/Ministry of Transport, Public Works, and Water Management: Haarlem/The Hague, 2008. 